\title{
The Effect of Artificial Weathering on Surface Properties of Thermally Modified Oriental Beech Wood
}

\section{Utjecaj umjetnog izlaganja vremenskim utjecajima na svojstva površine toplinski modificirane bukovine}

\author{
Original scientific paper • Izvorni znanstveni rad \\ Received-prispjelo: 20. 4. 2020. \\ Accepted-prihvaćeno: 26. 5. 2021. \\ UDK: $630 * 812.111 ; 630 * 814.11$ \\ https://doi.org/10.5552/drvind.2021.2020
}

(C) 2021 by the author(s). Licensee Faculty of Forestry and Wood Technology, University of Zagreb. This article is an open access article distributed under the terms and conditions of the Creative Commons Attribution (CC BY) license.

\begin{abstract}
The study aimed to determine some surface parameters such as surface roughness and color changes of thermally modified Oriental beech (Fagus orientalis L.) wood samples after 750 hours of artificial weathering. The results of the study showed that artificial weathering led to an increase in surface roughness of Oriental beech wood. Thermal modification interval of $210^{\circ} \mathrm{C}-230^{\circ} \mathrm{C}$ gave a smoother surface than unmodified samples after artificial weathering. Artificial weathering caused darker, reddish, and yellowish tone of unmodified and thermally modified Oriental beech wood. According to the study findings, surface properties of thermally modified Oriental beech wood were better than those of unmodified Oriental beech.
\end{abstract}

Keywords: thermal modification; Oriental beech wood; color; surface roughness; artificial weathering; construction materials

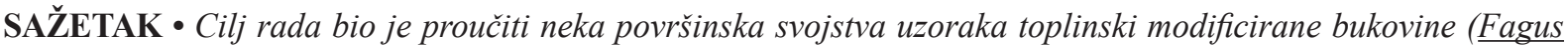
orientalis L.) poput hrapavosti površine i promjena boje nakon 750 sati umjetnog izlaganja uzoraka vremenskim utjecajima. Rezultati su pokazali da umjetno izlaganje vremenskim utjecajima uzrokuje povećanje hrapavosti površine uzoraka bukovine. Toplinskom modifikacijom pri temperaturi od $210-230{ }^{\circ} \mathrm{C}$ postiže se glađa površina od one koju imaju nemodificirani uzorci nakon umjetnog izlaganja vremenskim utjecajima. Umjetno izlaganje vremenskim utjecajima uzrokuje tamnjenje uzoraka te povećanje udjela crvenoga $i$ žutog tona na nemodificiranoj i toplinski modificiranoj bukovini. Dobiveni rezultati pokazuju da su svojstva površine toplinski modificirane bukovine bolja od površinskih svojstava nemodificirane bukovine.

Ključne riječi: toplinska modifikacija; bukovina; boja; hrapavost površine; umjetno izlaganje vremenskim utjecajima; konstrukcijski materijali

\footnotetext{
${ }^{1}$ Author is researcher at Mugla Sitki Kocman University, Koycegiz Vocational School, Department of Forestry, Mugla, Turkey.

2 Authors are researchers at Mugla Sitki Kocman University, Faculty of Technology Department of Wood Science and Technology, Mugla, Turkey.

${ }^{3}$ Author is researcher at Aydin Adnan Menderes University, Aydin Vocational School, Department of Furniture and Decoration, Aydin, Turkey.

${ }^{4}$ Author is researcher at Antalya Bilim University, Fine Arts and Architecture Faculty, Antalya, Turkey.

${ }^{5}$ Author is researcher at Artvin Coruh University, Faculty of Forestry, Artvin, Turkey.
} 


\section{INTRODUCTION}

\section{UVOD}

Wood has been preferred in the field of construction sector and furniture manufacture since ancient times, due to its natural beauty, thermal insulation, high strength, ease of use and processing ( $\mathrm{Su}, 1997)$. However, wood is readily decomposed by environmental factors, including water, solar rays, bacteria, fungi and insects, fire, etc. (Kiguchi and Evans, 1998). This problem may be decreased by using chemical or thermal treatments. There has been a rise in the chemical treatment of wooden materials to enhance its mechanical, physical, and other properties for building proposes (Su, 1997; Yalinkilic et al., 1999; Brelid et al., 2000). However, the harms of chemicals used in treatment to increase the durability of wood are discussed. The demand for treating wood with environmentally friendly substances is increasing.

Methods called heat treatment or thermal modification are made to improve the properties of wood without using chemicals (Johansson, 2008). Heat treatment at high temperatures causes serious changes in the properties of wood. Therefore, it can be said that a new material has been formed as a result of heat treatment (Sundqvist, 2004). Thermal modification can be made in order to ensure the dimensional stability of the wood by reducing the water absorption rate, as well as to protect against biological organisms (Akgul and Korkut, 2012). However, since thermal modification negatively affects the mechanical and physical properties of wood, it has some commercial disadvantages (Gunduz and Aydemir, 2009).

It is common to use wood outdoors in architecture. However, wooden surfaces exposed to outdoor weather conditions can quickly deteriorate. Since the lignin in wood easily absorbs ultraviolet (UV) light, the fact that lignin absorbs UV light causes significant depolymerization in the main structural components of wood (Evans et al., 2002). Some adverse conditions arising from weather conditions occur in the physical, mechanical, chemical and biological properties of wood and wood-based materials (Grelier et al., 2000; Zhang and Kamdem, 2000; Evans et al., 2005; Williams, 2005). It has been revealed as a result of scientific studies that the heat-treated wood material shows better resistance against weather conditions than the untreated wood (Temiz et al., 2006; Nuopponen et al., 2004; Ayadi et al., 2003). Due to the chromophoric lignin structure, the heat-treated wood material can interfere with the light absorption process and induce photostability (Srinivas and Pandey, 2012).

Turkoglu et al. (2015) exposed heat-treated wood to natural weathering for six months. After six months of natural weathering, they experimented with some surface properties of wood such as surface roughness, gloss, and color changes. After the natural weathering process, the experimental results showed that the surface properties of wood have improved after the heat treatment. They also concluded that, after heat treatment at high temperatures, natural weathering affects the surface properties of wood to a lesser extent. Kucuktuvek et al. (2017) investigated surface roughness characteristics of heat-treated Scots pine wood after weathering. They reported that heat-treated Scots pine wood had smooth surface after weathering. Toker et al. (2016) studied total color changes of heat-treated Oriental beech (Fagus orientalis L.) and Scots pine (Pinus sylvestris L.) woods after weathering. They found that total color changes of heat-treated Oriental beech (Fagus orientalis L.) and Scots pine (Pinus sylvestris L.) woods were lower than those of un-heated wood after weathering. Baysal et al. (2014), in an experimental study, investigated the gloss, surface roughness, and color change of the wooden test specimens after 500 hours of artificial weathering of heat-treated Scots pine (Pinus sylvestris). They stated that the surface properties of thermally modified Scots pine showed better surface properties as a result of artificial weathering than unmodified control samples. Garcia et al. (2014) reported that heat-treated teak sapwood (Tectona grandis) showed higher performance against color change after artificial weathering compared to control samples. Thus, wood material can become even more valuable as a result of heat treatment. The advantages of heat treatment can be listed as improved dimensional stability due to reduced hygroscopy, higher performance against degradation by microorganisms and insects, and dark color which is attractive to some users (Huang et al., 2012).

The number of scientific studies examining the change in the surface properties of wood materials treated above $200{ }^{\circ} \mathrm{C}$ after artificial weathering is limited. For this reason, in this study, Oriental beech wood (Fagus orientalis L.), which was heat-treated at temperatures above $200{ }^{\circ} \mathrm{C}$, is aimed to investigate color and surface roughness after artificial weathering.

\section{MATERIALS AND METHODS}

2. MATERIJALI I METODE

\subsection{Sample preparation}

2.1. Priprema uzoraka

Wood samples of $6 \mathrm{~mm} \times 75 \mathrm{~mm} \times 150 \mathrm{~mm}$ (radial by tangential by longitudinal) sized Oriental beech wood (Fagus orientalis L.) were prepared from air-dried wood. Wood samples were kept at $20{ }^{\circ} \mathrm{C}$ and $65 \%$ relative humidity for 2 weeks before the tests started.

\subsection{Thermal modification}

\subsection{Toplinska modifikacija}

The thermal modification was done in a laboratory oven with temperature control. Three different temperatures $\left(210{ }^{\circ} \mathrm{C}, 220{ }^{\circ} \mathrm{C}\right.$ and $\left.230{ }^{\circ} \mathrm{C}\right)$ were applied to Oriental beech samples under atmospheric pressure and heat treatment was performed in three different times $(0.5,1$, and 1.5 hours). Five replications were made for each treatment group.

\subsection{Artificial weathering}

2.3. Umjetno izlaganje vremenskim utjecajima

Artificial weathering test according to ASTM G154-60 (2006) standard was made on a QUV weathering device (Q-Lab, USA) equipped with eight UVA 
340 lamps. After the wooden specimens were exposed to 8-hour UV-ray irradiation cycles, 4 hours of condensation was applied on the QUV device for a total of 750 hours. The average radiation is at $340 \mathrm{~nm}$ wavelength $\left(\lambda_{\max }=340 \mathrm{~nm}\right)$ and its maximum intensity is $0.89 \mathrm{~W} /$ $\mathrm{m}^{2}$. The temperature during the light irradiation period and the condensation period was around $60^{\circ} \mathrm{C}$ and 50 ${ }^{\circ} \mathrm{C}$, respectively.

\subsection{Surface roughness}

According to DIN 4768 (1990) standard, roughness measurements were made with Mitutoyo Surftest SJ-301 device. In this study, the surface roughness parameter, such as average peak-valley height $(R z)$, was calculated. The surface roughness profile was scrutinized using the stylus with a diamond tip of $5 \mu \mathrm{m}$ radius and $90^{\circ}$ conical angle. The feed speed of the stylus was $0.5 \mathrm{~mm} / \mathrm{s} 1$ along $8 \mathrm{~mm}$ sampling length (Zhong et al., 2013). Five replications were made for each treatment group. Surface roughness measurements were made parallel to the fibers.

\subsection{Color test}

\subsection{Određivanje boje}

The three-dimensional CIELAB color space was used to quantify the color (Figure 1). Here, while the $L^{*}$ axis represents lightness, $a^{*}$, and $b^{*}$ denote color coordinates. The parameters $+a^{*}$ and $-a^{*}$ represent red and green, respectively, while the parameter $+b^{*}$ represents yellow and $-b^{*}$ represents blue. The $L^{*}$ parameter can range from 100 (white) to zero (black) (Zhang 2003). The colors of the specimens were measured with measurement geometry of $d / 8^{\circ}$ and a D65 illuminant by a colorimeter (X-Rite SP Series Spectrophotometer, X-ride Pantone, MI, USA). The color coordinates were measured on the surface of samples at the same five points before and after artificial weathering. The measuring spot was adjusted to be equal or not more than one-third of the distance from the center of this area to the receptor field stops. Five replications

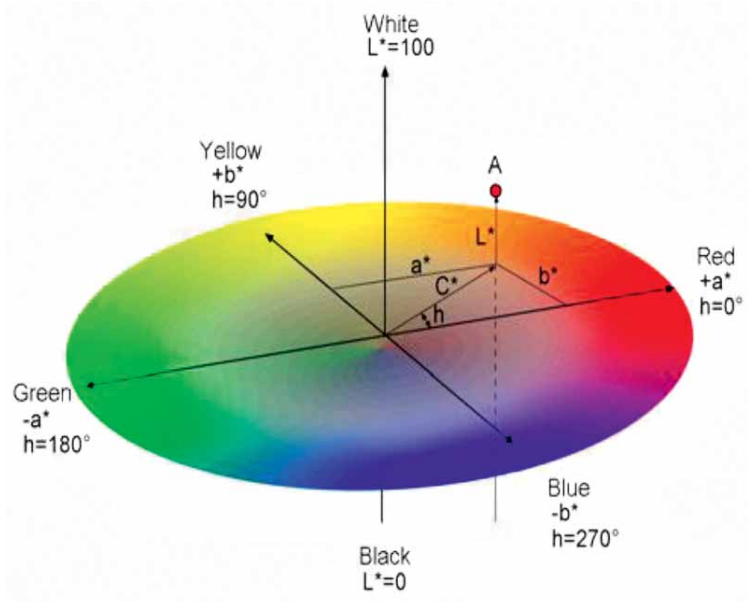

Figure 1 Three-dimensional $C I E L^{*} a^{*} b^{*}$ color space (Hunt, 1995)

Slika 1. Trodimenzionalni prostor boje $C I E L^{*} a^{*} b^{*}$ (Hunt, 1995.) were made for each treatment group. Color measurements were made parallel to the fibers.

The color difference, $\left(\Delta E^{*}\right)$ was determined for each wood as shown in the following Eqs. (ASTM D 1536-58 1964):

$$
\begin{gathered}
\Delta a^{*}=a_{f}{ }^{*}-\mathrm{a}_{\mathrm{i}}^{*} \\
\Delta b^{*}=b_{f}^{*}-b_{i}^{*} \\
\Delta L^{*}=L_{f}^{*}-L_{i}^{*} \\
\Delta E^{*}=\left[\left(\Delta a^{*}\right)^{2}+\left(\Delta b^{*}\right)^{2}+\left(\Delta L^{*}\right)^{2}\right]^{1 / 2}
\end{gathered}
$$

Where: $\Delta a^{*}, \Delta b^{*}$, and $\Delta L^{*}$ are the changes between the initial and final interval values.

\subsection{Statistical evaluations of test results}

2.6. Statistička analiza ispitnih rezultata

Experimental results were examined statistically. This examination was made with variance analysis and Duncan test. Duncan test with a $95 \%$ confidence level of surface roughness and total color change test results were evaluated with a computerized statistical program. Homogeneity groups (HG) revealed whether the results were statistically significant. The exponential letters $\left(\mathrm{x}^{\mathrm{a}, \mathrm{b}, \mathrm{c}, \mathrm{d}}\right)$ are given as homogeneity groups in Table 1 and 2 .

\section{RESULTS AND DISCUSSION}

\section{REZULTATI I RASPRAVA}

\subsection{Surface roughness}

3.1. Hrapavost površine

The $R z$ values used for surface roughness parameter before and after artificial weathering are presented in Table 1.

Before artificial weathering, the average $R z$ value of the unmodified control sample was 13.6. The test results indicated that, except for $0.5 \mathrm{~h}$ at $220{ }^{\circ} \mathrm{C}$ heat treatment, surface roughness values of all thermally modified Oriental beech wood samples were increased before weathering. Thermal modification gave a smoother surface than unmodified Oriental beech after artificial weathering. The increase in smoothness or reduction in roughness can be crucial for the use of solid wood. Wooden materials with rough surfaces require much more sanding than those with a smooth surface, which leads to a decrease in thickness of the material and, therefore, increases the losses due to the sanding process (Dundar et al., 2008). Besides, it ensures that losses in the planer are reduced, and high-quality surfaces are obtained (Sevim Korkut et al., 2008).

Surface roughness is considered to be a significant parameter to determine the wood surface quality, and many parameters affect the wood surface quality (Yildiz et al., 2013). The weathering exposure increased the roughness of the un-heated and thermal treated Oriental beech. After artificial weathering, the increasing range of $R z$ was from $26.03 \%$ to $75.26 \%$ for thermal modified Oriental beech wood samples, while the increase of $R z$ by $106.63 \%$ was observed for unmodified Oriental beech. This is because artificial 
Turkoglu, Toker, Baysal, Gunduz, Altay, Kucuktuvek, Peker: The Effect of Artificial..........

Table 1 Surface roughness values of Oriental beech samples before and after artificial weathering

Tablica 1. Vrijednosti hrapavosti površine uzoraka bukovine prije i nakon umjetnog izlaganja vremenskim utjecajima

\begin{tabular}{|c|c|c|c|c|}
\hline \multirow{2}{*}{$\begin{array}{c}\text { Thermal treatment, }{ }^{\circ} \mathbf{C} \\
\text { Toplinska obrada, }{ }^{\circ} \mathrm{C}\end{array}$} & \multirow{2}{*}{$\begin{array}{c}\text { Hours } \\
\text { Sati }\end{array}$} & \multirow{2}{*}{$\begin{array}{c}\text { Before artificial weathering } \\
\text { Prije umjetnog izlaganja } \\
\text { vremenskim utjecajima } \\
\text { Rz, } \mu \mathrm{m} \\
\text { (Mean / srednja vrijednost) }\end{array}$} & \multicolumn{2}{|c|}{$\begin{array}{c}\text { After } \mathbf{7 5 0} \text { h artificial weathering } \\
\text { Nakon } 750 \text { h umjetnog izlaganja } \\
\text { vremenskim utjecajima }\end{array}$} \\
\hline & & & $\begin{array}{c}R z, \mu \mathrm{m} \\
\text { (Mean / srednja } \\
\text { vrijednost) }\end{array}$ & $\begin{array}{c}R z, \mu \mathrm{m} \\
\text { Increases / } \\
\text { Povećanje, \% }\end{array}$ \\
\hline $\begin{array}{c}\text { Unmodified (Control) } \\
\text { Nemodificirani (kontrolni) uzorci }\end{array}$ & - & $13.60(2.76)^{*}$ & $28.10(3.63)$ & $(+) 106.63^{\mathrm{a} * *}$ \\
\hline \multirow{3}{*}{210} & 0.5 & $16.92(2.45)$ & $27.65(4.47)$ & $(+) 63.42^{\mathrm{bc}}$ \\
\hline & 1.0 & $16.82(3.52)$ & $26.15(3.64)$ & $(+) 55.12^{\mathrm{c}}$ \\
\hline & 1.5 & $20.17(1.73)$ & $25.96(0.89)$ & $(+) 28.70^{\mathrm{d}}$ \\
\hline \multirow{3}{*}{220} & 0.5 & $10.27(2.47)$ & $18.00(4.02)$ & $(+) 75.26^{\mathrm{b}}$ \\
\hline & 1.0 & $13.86(2.60)$ & $22.13(2.96)$ & $(+) 59.73^{\mathrm{bc}}$ \\
\hline & 1.5 & $14.76(3.32)$ & $18.97(4.55)$ & $(+) 28.54^{\mathrm{d}}$ \\
\hline \multirow{3}{*}{230} & 0.5 & $20.51(5.49)$ & $31.49(2.00)$ & $(+) 53.50^{c}$ \\
\hline & 1.0 & $17.54(3.73)$ & $23.50(2.42)$ & $(+) 33.99^{d}$ \\
\hline & 1.5 & $17.25(3.81)$ & $21.74(5.32)$ & $(+) 26.03^{d}$ \\
\hline
\end{tabular}

* The values in parenthesis are standard deviations. Five replications were made for each group. / Vrijednosti u zagradama standardne su devijacije. ${ }^{* *}$ The exponential letters are given as homogeneity groups (HG). / Slova označuju homogene grupe (HG).

weathering affects primarily the surface of wood, and causes slow abrasion of wood fibers from the surface (Williams et al., 2001). According to the results of the study, rising temperature and prolonged modification time led to a lower surface roughness of Oriental beech after artificial weathering. Turkoglu et al. (2015) investigated the effect of weathering on the roughness of thermally treated Oriental beech. They reported that heat-treated samples reduced the effects of weathering on surface roughness. Baysal et al. (2014) explained that the unheated Scots pine wood gave a rougher surface than the heat-treated Scots pine wood after artificial weathering. The findings of this study are compatible with the above-mentioned researchers' results.

\subsection{Color changes}

\subsection{Promjena boje}

Table 2 shows the color changes of thermally modified Oriental beech before and after artificial weathering.

As could be expected, $L^{*}$ values of heat-treated Oriental beech wood were lower than those of un-heated (control) wood. This is because thermal modification caused the decrease of $L^{*}$ values of Oriental beech wood. Therefore, Oriental beech wood becomes darker after thermal modification. This tonality is generally developed with increasing temperature and durations. These findings are generally compatible with previous

Table 2 Color changes of Oriental beech samples before and after artificial weathering

Tablica 2. Promjena boje uzoraka bukovine prije i nakon umjetnog izlaganja vremenskim utjecajima

\begin{tabular}{|c|c|c|c|c|c|c|c|c|c|c|c|}
\hline \multirow[t]{2}{*}{$\begin{array}{c}\text { Thermal } \\
\text { treatment, }{ }^{\circ} \mathbf{C} \\
\text { Toplinska } \\
\text { obrada, }{ }^{\circ} \mathrm{C}\end{array}$} & \multirow[t]{2}{*}{$\begin{array}{c}\text { Hours } \\
\text { Sati }\end{array}$} & \multicolumn{3}{|c|}{\begin{tabular}{|c|} 
Before artificial \\
weathering \\
Prije umjetnog izlaganja \\
vremenskim utjecajima \\
\end{tabular}} & \multicolumn{3}{|c|}{$\begin{array}{c}\text { After } \mathbf{7 5 0} \text { h artificial } \\
\text { weathering } \\
\text { Nakon } 750 \text { h umjetnog izlaganja } \\
\text { vremenskim utjecajima }\end{array}$} & \multicolumn{3}{|c|}{$\begin{array}{l}\text { Color changes } \\
\text { Promjena boje }\end{array}$} & \multirow{2}{*}{$\begin{array}{c}\begin{array}{c}\text { Total color } \\
\text { changes } \\
\text { Ukupna }\end{array} \\
\text { promjena boje } \\
\Delta E^{*}\end{array}$} \\
\hline & & $L_{\mathrm{i}}^{*}$ & $a_{\mathrm{i}}^{*}$ & $b_{i}^{*}$ & $L_{\mathrm{f}}^{*}$ & $a_{\mathrm{f}}^{*}$ & $b_{\mathrm{f}}^{*}$ & $\Delta L^{*}$ & $\Delta a^{*}$ & $\Delta b^{*}$ & \\
\hline $\begin{array}{l}\text { Unmodified } \\
\text { (Control) } \\
\text { Nemodificirani } \\
\text { (kontrolni) } \\
\text { uzorci }\end{array}$ & - & 71.28 & 9.76 & 18.32 & 57.22 & 13.36 & 27.95 & -14.06 & $3.60^{\mathrm{a}}$ & $9.63^{\mathrm{a}}$ & $17.42^{\mathrm{a} *}$ \\
\hline \multirow{3}{*}{210} & 0.5 & 44.66 & 7.94 & 16.11 & 42.37 & 12.29 & 22.56 & -2.29 & 4.35 & 6.45 & $8.11^{\mathrm{b}}$ \\
\hline & 1.0 & 43.70 & 7.74 & 15.80 & 41.49 & 10.17 & 20.04 & -2.21 & 2.43 & 4.24 & $5.36^{\mathrm{c}}$ \\
\hline & 1.5 & 43.08 & 7.32 & 14.44 & 39.2 & 11.68 & 17.51 & -3.88 & 4.36 & 3.07 & $6.59^{\mathrm{bc}}$ \\
\hline \multirow{3}{*}{220} & 0.5 & 41.34 & 7.87 & 14.94 & 37.5 & 12.01 & 20.31 & -3.84 & 4.14 & 5.37 & $7.79^{b}$ \\
\hline & 1.0 & 34.74 & 7.02 & 12.48 & 34.67 & 8.5 & 14.56 & -0.07 & 1.48 & 2.08 & $2.55^{\mathrm{e}}$ \\
\hline & 1.5 & 34.42 & 6.76 & 12.45 & 33.68 & 7.6 & 13.43 & -0.74 & 0.84 & 0.98 & $1.49^{\mathrm{e}}$ \\
\hline \multirow{3}{*}{230} & 0.5 & 37.27 & 7.59 & 13.57 & 35.33 & 9.17 & 17.54 & -1.94 & 1.58 & 3.97 & $4.69^{\mathrm{cd}}$ \\
\hline & 1.0 & 28.85 & 5.30 & 8.46 & 26.43 & 6.45 & 9.39 & -2.42 & 1.15 & 0.93 & $2.83^{\mathrm{de}}$ \\
\hline & 1.5 & 34.05 & 7.22 & 13.10 & 33.28 & 8.51 & 15.17 & -0.77 & 1.29 & 2.07 & $2.56^{\mathrm{e}}$ \\
\hline
\end{tabular}

*The exponential letters are given as homogeneity groups (HG). Five replications were made for each group. / Slova označuju homogene grupe $(H G)$. Za svaku je grupu pripremljeno pet uzoraka. 
studies (Aksoy et al., 2011; Baysal et al., 2014; Militz, 2002; Yildiz et al., 2011; Toker et al., 2016). The decreases of $L^{*}$ values of thermally modified wood can be attributed to changes in lignin structure and noncellulosic polysaccharides (Grelier et al., 2000; Petric et al., 2004; Hon and Chang, 1985). While the (+) values of $a^{*}$ show that Oriental beech turned to red, $(+)$ values of $b^{*}$ show that Oriental beech turned to yellow. According to our results, the thermally modified wood surface turned to red and yellow after thermal modification. Baysal et al. (2014) found that, while $a^{*}$ values decreased with the increase in temperature and time, the $b^{*}$ values increased initially and then decreased at temperatures used. Akgul and Korkut (2012) investigated the color characteristics of thermally treated U1udag fir wood. According to their findings, with higher treatment temperature and durations, yellow tone initially increased and then decreased. Gunduz and Aydemir (2009) studied color characteristics of heattreated Hornbeam wood. They found that, while the $b^{*}$ values increased slightly at low temperature and durations, higher temperatures caused the decrease of $b^{*}$ values of Hornbeam wood. Our results showed that artificial weathering caused the decrease of $L^{*}$ values of thermally modified and unmodified wood. Negative values of $\Delta L^{*}$ were observed after weathering. Our results showed that decreases in $L^{*}$ values of thermally treated wood were lower compared to those of un-heated wood. For example, while $\Delta L^{*}$ of unmodified wood was 14.06 , it was between $(-0.07)$ and $(-3.88)$ for thermally modified wood. Baysal et al. (2014) investigated lightness values of thermally modified wood after artificial weathering. They determined that $\Delta L *$ values of thermally modified wood were lower compared to unmodified wood after artificial weathering. Our results are compatible with Baysal's findings (2014).

The color change results of the study showed that thermally modified and unmodified wood surface turned to red after weathering. After weathering, $\Delta a^{*}$ changed between 0.84 to 4.36 . Sivrikaya et al. (2015) studied color changes of thermally modified Scots pine wood after artificial weathering. They reported that the $\Delta a^{*}$ values of Scots pine increased after weathering. Baysal et al. (2014) studied $\Delta a^{*}$ changes of thermally modified wood. They determined that thermally modified Scots pine wood gave positive $\Delta a^{*}$ values after artificial weathering. Our results are compatible with the aforementioned studies. According to our results, thermally modified and unmodified wood showed positive $\Delta b^{*}$ values after artificial weathering. It can be due to the modification of some chromophoric groups of lignin (Grelier et al., 2000). Moreover, $\Delta b^{*}$ of unmodified wood was higher compared to thermally modified wood. Baysal et al. (2014) studied color changes of Scots pine after artificial weathering. They determined that Scots pine gave positive $\Delta b^{*}$ values after artificial weathering. Also, they found that, in general, $\Delta b^{*}$ values decreased with increasing temperature and durations. Our results are compatible with the Baysal et al. (2014) findings. $\Delta E^{*}$ values of thermally modified Oriental beech were lower compared to unmodified wood. For example, $\Delta E^{*}$ of unmodified wood was 17.42 , while it varied between 1.49 and 8.11 in thermally modified wood. There was a statistically significant difference between $\Delta E *$ values of the unmodified (control) and thermally modified Oriental beech wood $(p \leq 0.05)$. In general, total color changes in wood decreased with temperature and duration after artificial weathering.

\section{CONCLUSIONS}

4. ZAKLJUČAK

Thermal modification reduced the surface roughness and color changes of Oriental beech after artificial weathering compared to untreated beech wood. The surface of heated and un-heated wood was darkened due to artificial weathering exposure. However, thermally modified wood gave a lighter surface than unmodified wood after artificial weathering. Oriental beech wood tended to be reddish and yellowish after artificial weathering. Total color changes of heat treated Oriental beech wood were lower compared to those of un-heated wood. Generally, higher treatment temperature and treatment time resulted in lower surface roughness and total color changes of Oriental beech wood after artificial weathering.

\section{REFERENCES}

\section{LITERATURA}

1. Akgul, M.; Korkut, S., 2012: The effect of heat treatment on some chemical properties and colour in Scots pine and Uludağ fir wood. African Journal of Biotechnology, 7 (21): 2854-2859. https://doi.org/10.5897/IJPS12.281.

2. Aksoy, A.; Deveci, M.; Baysal, E.; Toker, H., 2011: Colour and gloss changes of Scots pine after heat modification. Wood Research, 56 (3): 329-336.

3. Ayadi, N.; Lejeune, F.; Charrier, F.; Charrier, B.; Merlin, A., 2003: Color stability of heat-treated wood during artificial weathering. Holz als Roh- und Werkstoff, 61: 221-226. https://doi.org/10.1007/s00107-003-0389-2.

4. Baysal, E.; Degirmentepe, S.; Simsek, H., 2014: Some surface properties of thermally modified Scots pine after artificial weathering. Maderas, Ciencia y Tecnología, 16 (3): 355-364.

5. Brelid, P. L.; Simonson, R.; Bergman, O.; Nilsson, T., 2000: Resistance of acetylated wood to biological degradation. Holz als Roh- und Werkstoff, 58 (5): 331-337. https://doi.org/10.1007/s001070050439.

6. Dundar, T.; As, N.; Korkut, S.; Unsal Ö., 2008: The effect of boiling time on the surface roughness of rotary-cut veneers from Oriental beech (Fagus orientalis L.). Journal of Materials Processing Technology, 199 (1-3): 119-123. https://doi.org/10.1016/j.jmatprotec.2007.07.036.

7. Evans, P. D.; Owen, N. L.; Schmid, S.; Webster, R. D., 2002: Weathering and photostability of benzoylated wood. Polymer Degradation and Stability, 76 (2): 291303. https://doi.org/10.1016/S0141-3910(02)00026-5.

8. Evans, P.; Chowdhury, M. J.; Mathews, B.; Schmalzl, K.; Ayer, S.; Kiguchi, M.; Kataoka, Y., 2005: Weathering and surface protection of wood. In: Handbook of environmental degradation of materials, Kutz, M. (ed.). William Andrew Publishing, New York, pp. 277-297.

9. Garcia, R. A.; de Oliveira Lopes, J.; do Nascimento, A. M.; de Figueiredo Latorraca, J. V., 2014: Color stability 
of weathered heat-treated teak wood. Maderas, Ciencia y Tecnología, 16 (4): 453-462.

10. Grelier, S.; Castellan, A.; Kamdem, D. P., 2000: Photoprotection of copper amine treated wood. Wood and Fiber Science, 32 (2): 196-202.

11. Gunduz, G.; Aydemir, D., 2009: Some physical properties of heat-treated Hornbeam (Carpinus betulus) wood. Drying Technology, 27 (5): 714-720. https://doi.org/10.1080/07373930902827700.

12. Hon, D. N. S.; Chang, S. T., 1985: Photoprotection of wood surfaces by wood-ion complexes. Wood and Fiber Science, 17 (1): 92-100.

13. Huang, X.; Kocaefe, D.; Kocaefe, Y.; Boluk, Y.; Pichette, A., 2012: A spectrocolorimetric and chemical study on color modification of heat-treated wood during artificial weathering. Applied Surface Science, 258 (14): 5360-5369.

14. Hunt, R., 1995: Measuring color, 2. ed. Ellis Horwood Limited, Hertfordshire.

15. Johansson, D., 2008: Heat treatment of solid wood: Effects on absorption, strength and colour. PhD Thesis, Luleå University of Technology, Skelleftea, Sweden, pp. 142.

16. Kiguchi, M.; Evans, P. D., 1998: Photostabilization of wood surface using a grafted benzophenone UV absorber. Polymer Degradation Stability, 61: 33-45. https://doi.org/10.1016/S0141-3910(97)00124-9.

17. Kucuktuvek, M.; Baysal, E.; Turkoglu, T.; Peker, H.; Gunduz, A.; Toker, H., 2017: Surface characteristics of Scots pine wood heated at high temperatures after weathering. Wood Research, 62 (6): 905-918.

18. Militz, H., 2002: Thermal treatment of wood: European Processes and their background. In: Proceedings of International Research Group on Wood Preservation. Section 4-Processes, No. IRG/WP 02-40241.

19. Nuopponen, M.; Wikberg, H.; Vuorinen, T.; Maunu, S. L.; Jämsä, S.; Viitaniemi, P., 2004: Heat-treated softwood exposed to weathering. Journal of Applied Polymer Science, 91 (4): 2128-2134. https://doi.org/10.1002/app.13351.

20. Petric, M.; Kricej, B.; Humar, H.; Pavlic, M.; Tomazic, M., 2004: Patination of cherry wood and spruce wood with ethanolamine and surface finishes. Surface Coatings International. Part B: Coatings Transactions, 87 (B3): 195-201. https://doi.org/10.1007/BF02699635.

21. Sevim Korkut, D.; Korkut, S.; Bekar, I.; Budakc1, M.; Dilik, T.; Cakıcier, N., 2008: The effects of heat treatment on the physical properties and surface roughness of Turkish hazel (Corylus colurna L.) wood. International Journal of Molecular Sciences, 9 (9): 1772-1783. https://doi.org/10.3390/ijms9091772.

22. Sivrikaya, H.; Ekinci, E.; Can, A.; Taşdelen, M.; Gökmen, K., 2015: Effect of heat treatment on the weathering and hardness properties of some wood species. In: Proceedings of the $11^{\text {th }}$ Meeting of the Northern European Network for Wood Sciences and Engineering (WSE), September 14-15, Poznan University of Life Sciences, Poznan, Poland, pp. 83-91.

23. Srinivas, K.; Pandey, K. K., 2012: Effect of heat treatment on color changes, dimensional stability, and mechanical properties of wood. Journal of Wood Chemistry and Technology, 32 (4): 304-316. https://doi.org/10.1080/02773813.2012.674170.

24. Su, W. Y., 1997: Development of fire-retardant wood composites using boron compounds and their evaluation methods. M. Sc. Thesis, Kyoto University, Kyoto, Japan, pp. 126.

25. Sundqvist, B., 2004: Colour changes and acid formation in wood during heating. Doctoral Thesis, Luleå University of Technology, Sweden, pp. 50.

26. Temiz, A.; Terziev, N.; Jacobsen, B.; Eikenes, M., 2006: Weathering, water absorption, and durability of silicon, acetylated, and heat-treated wood. Journal of Applied Polymer Science, 102 (5): 4506-4513. https://doi.org/10.1002/app.24878.

27. Toker, H.; Baysal, E.; Turkoglu, T.; Kart, S.; Sen, F.; Peker, H., 2016: Surface characteristics of oriental beech and Scots pine woods heat-treated above $200{ }^{\circ} \mathrm{C}$. Wood Research, 61(1): 43-54.

28. Turkoglu, T.; Toker, H.; Baysal, E.; Kart, S.; Yuksel, M.; Ergun, M. E., 2015: Some surface properties of heat treated and natural weathered Oriental beech. Wood Research, 60 (6): 881-890.

29. Williams, R. S.; Kanaebe, M. T.; Sotos, P. G.; Feist, W. C., 2001: Erosion rates of wood during natural weathering. Part 1: Effects of grain angle and surface texture. Wood and Fiber Science, 33 (1): 31-42.

30. Williams, R. S., 2005: Weathering of wood. In: Handbook of wood chemistry and wood composites, Rowell, R. (ed.). CRC Press, Florida, USA, pp. 139-185.

31. Yalinkilic, M. K.; Takahashi, M.; Imamura, Y.; Gezer, E. D.; Demirci, Z.; Ilhan, R., 1999: Boron addition to non or low formaldehyde cross-linking reagents to enhance biological resistance and dimensional stability for wood. Holz als Roh- und Werkstoff, 57 (1): 151-163. https://doi.org/10.1007/s001070050358.

32. Yildiz, S.; Yildiz, U. C.; Tomak, E. D., 2011: The effects of natural weathering on the properties of heat-treated alder wood. BioResources, 6 (4): 2504-2521. https://doi.org./10.15376/biores.6.3.2504-2521.

33. Yildiz, S.; Tomak, E. D.; Yildiz, U. C.; Ustaomer, D., 2013: Effect of artificial weathering on the properties of heat-treated wood. Polymer Degradation Stability, 98(8): 1419-1427. https://doi.org/10.1016/j.polymdegradstab.2013.05.004.

34. Zhang, J.; Kamdem, P. D., 2000: Weathering of copperamine treated wood. In: Proceedings of International Research Group on Wood Preservation (IRG 00- 40155), Kona, Hawaii. https://doi.org/10.1016/j.apsusc.2009.08.071.

35. Zhang, X., 2003: Photo-resistance of alkylammonium compound treated wood. M. Sc. Thesis, University of British Columbia, Canada, pp. 154.

36. Zhong, Z. W.; Hiziroglu, S.; Chan, C. T. M., 2013: Measurement of the surface roughness of wood based materials used in furniture manufacture. Measurement, 46: 1482-1487. https://doi.org/10.1016/j.measurement.2012.11.041.

37. ***ASTM D1536-58, 1964: Tentative method of test color difference using the colormaster differential colorimeter. ASTM International, PA, USA.

38. ***ASTM G154-60, 2006: Standard practice for operating fluorescent light apparatus for UV exposure of nonmetallic materials. ASTM International, PA, USA.

39. ***DIN 4768, 1990: Determination of values of surface roughness parameters $\mathrm{R}_{\mathrm{a}}, \mathrm{R}_{\mathrm{z}}, \mathrm{R}_{\max }$ using electrical contact (stylus) instruments, concepts and measuring conditions.

\section{Corresponding address:}

\section{CAGLAR ALTAY}

Aydin Adnan Menderes University

Aydin Vocational School

Department of Furniture and Decoration

Aydin, TURKEY

e-mail: caglar.altay@adu.edu.tr 